\title{
Primary ductal adenocarcinoma of the lacrimal gland: case report
}

\author{
Adenocarcinoma ductal primário da glândula lacrimal: relato de caso
}

Renato Wendell Ferreira Damasceno $0^{1,2}$, Leonard M. Holbach $^{1}$

\begin{abstract}
A 78-year-old male patient presented with double vision, painless palpable mass under the right superolateral orbital rim, downward displacement and restricted adduction of the right eye. His visual acuity was 20/50 OD and 20/20 OS. Hertel exophthalmometry was $21 \mathrm{~mm}$ OD and $17 \mathrm{~mm}$ OS. Computed tomographic scans showed an infiltrative orbital mass with ill-defined, irregular margins, involving the lacrimal gland and the lateral rectus muscle. The patient underwent an anterior transcutaneous transseptal orbitotomy with incisional biopsy and surgical debulking. Histopathologic evaluation revealed primary ductal adenocarcinoma of the lacrimal gland. Following the metastatic work up, he underwent an eyelid-sparing orbital exenteration. Microscopically, the tumor elements were characterized by large polygonal cells with vesicular nuclei, prominent nucleoli and amphophilic cytoplasm. The tumor components comprised duct-type structures with papillary and cribriform patterns, surrounded by prominent basement membrane. The tumor cells were positive for cytokeratin-7, matrix metalloproteinase (MMP)-2, MMP-9, MMP-13 and proto-oncogene Her-2/neu, but negative for cytokeratin-5, cytokeratin-20, p63, prostate-specific antigen, S-100 protein and thyroid transcription factor. These histopathologic findings were compatible with poorly differentiated ductal adenocarcinoma of the lacrimal gland, T3NOMO. Twenty-four months after orbital exenteration, the patient was diagnosed with ipsilateral parotid gland and cervical lymph node metastases and died of disease.
\end{abstract}

Keywords: Lacrimal gland/pathology; Adenocarcinoma/surgery; Matrix metalloproteinase 2; Matrix metalloproteinase 9; Matrix metalloproteinase 13; Case reports

\section{RESUMO}

Paciente do sexo masculino e com 78 anos de idade apresentou diplopia, massa palpá vel abaixo da margem orbitária direita, deslocamento inferior do bulbo ocular direito e limitação da adução do olho direito. A acuidade visual foi 20/50 OD e 20/20 OE. A exoftalmometria de Hertel foi $21 \mathrm{~mm} O D$ e $17 \mathrm{~mm}$ OE. Tomografia computadorizada mostrou uma massa orbitária, infiltrativa e com margens irregulares, envolvendo a glândula lacrimal e o músculo reto lateral. O paciente foi submetido a uma orbitotomia anteriorcombiópsia incisional. Oexamehistopatológicorevelou adenocarcinomaductal primário da glândula lacrimal. Em seguida, o paciente foi submetido a uma exenteração orbitária com preservação das pálpebras. Microscopicamente, os elementos tumorais foram caracterizados por células poligonais grandes com citoplasma anfofílico, núcleo vesicular enucléolo proeminente. Os componentes tumorais incluíram estruturas ductais com padrões cribriforme e papilifero e cercadas por membrana basal proeminente. As células tumorais foram positivas para citoqueratina 7, metaloproteinase 2 da matriz, metaloproteinase 9 da matriz, metaloproteinase 13 da matrize Her-2/neu, mas negativas para citoqueratina 5, citoqueratina 20, p63, antígeno prostáticoespecífico, proteínas-100 efator de transcrição da tiroide. Estes achados histopatológicos foram compatíveis como diagnósticodeadenocarcinomaductalpouco diferenciadodaglândula lacrimal, T3NOMO. Vinte e quatro meses após a exenteração orbitária, o paciente foi diagnosticado com metástases nos linfonodos cervicais ipsilaterais ena glândula parótidaipsilateralefaleceu.

Descritores: Glândula lacrimal/patologia;Adenocarcinoma/cirurgia; Metaloproteinase 2 da matriz; Metaloproteinase 9 da matriz; Metaloproteinase 13 da matriz; Relatos de casos

\section{INTRODUCTION}

Lacrimal gland fossa lesions represent 10\% of orbital space-occupying lesions and may be divided into three categories: inflammatory, lymphoproliferative, and epithelial lesions ${ }^{(1)}$. Epithelial tumors constitute about one third of lacrimal gland fossa lesions ${ }^{(1)}$. The most common epithelial lacrimal gland tumors are pleomorphic adenoma, adenoid cystic carcinoma and not otherwise specified adenocarcinoma ${ }^{(1)}$. Distinct subtypes of lacrimal gland adenocarcinoma such as primary ductal adenocarcinoma have been recently reported in the literature ${ }^{(2-8)}$.

The purpose of this case report was to describe the clinical and pathologic findings of a patient with primary ductal adenocarcinoma of the lacrimal gland.

\section{CASE REPORT}

A 78-year-old man had double vision, painless palpable mass under the right superolateral orbital rim, downward displacement and restricted adduction of the right eye. His visual acuity was 20/50
OD and 20/20 OS. Hertel exophthalmometry was $21 \mathrm{~mm}$ OD and $17 \mathrm{~mm}$ OS. Computed tomographic scans showed an infiltrative orbital mass with ill-defined, irregular margins involving the lacrimal gland and the lateral rectus muscle. Differential diagnosis included chronic inflammatory diseases, lymphoproliferative lesions and lacrimal gland tumors. The patient underwent an anterior transcutaneous transseptal orbitotomy with incisional biopsy and surgical debulking. Intraoperativelly, an ill-defined mass with infiltration of the lacrimal gland and the lateral rectus muscle was observed. Histopathologic examination revealed primary ductal adenocarcinoma carcinoma of the lacrimal gland. Following the metastatic work up (involvement of the regional lymph nodes, lungs and remote viscera was not detectable using clinical examination, ultrasonography and computed tomography), the patient underwent an eyelid-sparing orbital exenteration with subsequent fitting of a bone-integrated prosthesis.

Macroscopically, the mass measured $24 \times 15 \times 10 \mathrm{~mm}$. The tumor components comprised duct-type structures with papillary and cribriform patterns, surrounded by prominent basement membrane
Submitted for publication: February 17, 2011

Accepted for publication: June 15, 2011

Study carried out at the Department of Ophthalmology and Eye Hospital, Friedrich-Alexander University of Erlangen-Nuremberg, Germany.

Physician, Department of Ophthalmology and Eye Hospital, Friedrich-Alexander University of Erlangen-Nuremberg, Germany.

Physician, Department of Ophthalmology and Vision Institute, Universidade Federal de São Paulo UNIFESP - São Paulo (SP), Brazil.
Funding: No specific financial support was available for this study.

Disclosure of potential conflicts of interest: R.W.F.Damasceno, None; L.M.Holbach, None.

Correspondence address: Renato W. Damasceno. Department of Ophthalmology and Vision Institute Federal University of São Paulo. Rua Botucatu 821 - São Paulo (SP) - 04023-062 - Brazil E-mail: renato.damasceno@unifesp.br / renato.damasceno@uk-erlangen.de 
(Figure $1 \mathrm{~A}$ and B). Microscopically, the tumor elements were characterized by large polygonal cells with vesicular nuclei, prominent nucleoli and amphophilic cytoplasm (Figure 1B). No mucin was identified using periodic acid-Schiff stain (Figure 1C). The tumor cells displaying a high proliferation rate were positive for cytokeratin-7, matrix metalloproteinase (MMP)-2, MMP-9, MMP-13 and proto-oncogene Her-2/neu, but negative for cytokeratin-5, cytokeratin-20, p63, prostate-specific antigen, S-100 protein and thyroid transcription factor (Figure 1D, 1E, 1F). The histopathologic findings of this infiltrative mass were compatible with poorly differentiated ductal adenocarcinoma of the lacrimal gland, T3NOMO according to the 2010 American Joint Committee on Cancer staging system. Twenty-four months after orbital exenteration, the patient was diagnosed with ipsilateral parotid gland and cervical lymph node metastases and died of disease.

\section{DISCUSSION}

Primary ductal adenocarcinoma of the lacrimal gland is a highgrade neoplasm arising from the ductal epithelium. This subtype of lacrimal gland adenocarcinoma was firstly described by Katz et al. in $1996^{(8)}$. Since then, other cases have demonstrated an aggressive clinical behavior and poor prognosis $(3-5,7)$. Of 7 patients with primary ductal adenocarcinoma, 2 had lymph node involvement (cervical lymph nodes(4) and mediastinal lymph nodes $\left.{ }^{(3)}\right), 4$ had distant metastases (brain ${ }^{(5,7)}$, common bile duct ${ }^{(5)}$, liver ${ }^{(5)}$, lung ${ }^{(5)}$, pancreas ${ }^{(5)}$, parotid
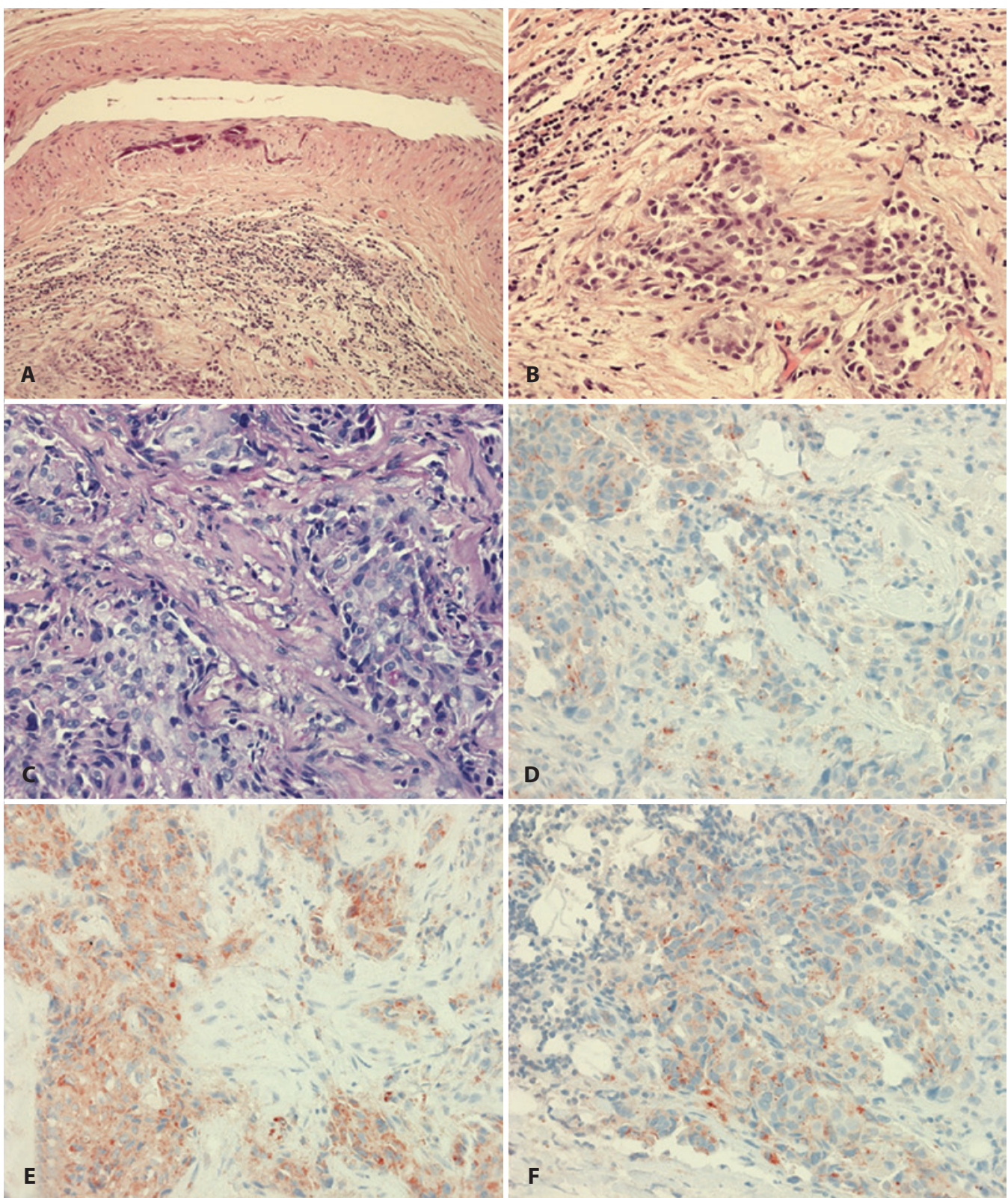

Figure 1. Histologic sections of a lacrimal gland specimen from a patient with primary ductal adenocarcinoma. A) Low magnification showed tumor cells infiltrating the adjacent capsule and orbital soft tissues (Stain, hematoxylin-eosin; original magnification, 25x). B) High magnification revealed large polygonal cells with vesicular nuclei, prominent nucleoli and amphophilic cytoplasm (Stain, hematoxylin-eosin; original magnification, 200x). C) No mucin was identified (Stain, periodic acid-Schiff; original magnification, 200x). D, E, F) Tumor cells were positive for matrix metalloproteinase (MMP)-2, MMP-9 and MMP-13 (Original magnification, 200x). 
gland $^{(4)}$, pelvic bone(3) skin $^{(3)}$ and vertebral column $\left.{ }^{(3)}\right)$ and 2 died of disease $\mathrm{e}^{(3,5)}$.

In the current article, the tumor cells were positive for MMP-2, MMP-9 and MMP-13. The expression of matrix metalloproteinases is unknown in primary ductal adenocarcinoma of the lacrimal gland. MMP-2 was previously associated with worse prognosis in several types of salivary gland carcinoma ${ }^{(9)}$. In addition, MMP-9 and MMP-13 were specifically related to poor prognosis in duct salivary carcinoma, which is regarded as histologically and immunohistochemically similar to primary ductal adenocarcinoma of the lacrimal gland ${ }^{(10)}$.

Ophthalmologists and pathologists must remember that the lacrimal gland can develop aggressive tumors, such as primary ductal adenocarcinoma. Because there are few reports of lacrimal gland ductal adenocarcinoma, its clinical behavior, prognosis and treatment are still unknown. Therefore, early recognition of this new entity may support to delineate its management.

\section{REFERENCES}

1. Santos RR, Damasceno RW, de Pontes FS, Cursino SR, Nishiwaki-Dantas MC, Vital Filho J, Dantas PE. Ten-year follow-up of a case series of primary epithelial neoplasms of the lacrimal gland: clinical features, surgical treatment and histopathological findings. Arq Bras Oftalmol. 2010;73(1):33-9.

2. Lee YJ, Oh YH. Primary ductal adenocarcinoma of the lacrimal gland. Jpn J Ophthalmol. 2009;53(3):268-70.

3. Kim MJ, Hanmantgad S, Holodny Al. Novel management and unique metastatic pattern of primary ductal adenocarcinoma of the lacrimal gland. Clin Experiment Ophthalmol. 2008;36(2):194-6.

4. Milman T, Shields JA, Husson M, Marr BP, Shields CL, Eagle RC Jr. Primary ducta adenocarcinoma of the lacrimal gland. Ophthalmology. 2005;112(11):2048-51.

5. Kurisu Y, Shibayama Y, Tsuji M, Kurokawa A, Akutagawa H, Egashira Y, et al. A case of primary ductal adenocarcinoma of the lacrimal gland: histopathological and immunohistochemical study. Pathol Res Pract. 2005;201(1):49-53.

6. Krishnakumar S, Subramanian N, Mahesh L, Mohan ER, Biswas J. Primary ductal adenocarcinoma of the lacrimal gland in a patient with neurofibromatosis. Eye (Lond). 2003;17(7):843-5.

7. Nasu M, Haisa T, Kondo T, Matsubara O. Primary ductal adenocarcinoma of the lacrimal gland. Pathol Int. 1998;48(12):981-4.

8. Katz SE, Rootman J, Dolman PJ, White VA, Berean KW. Primary ductal adenocarcinoma of the lacrimal gland. Ophthalmology. 1996;103(1):157-62

9. Nagel H, Laskawi R, Wahlers A, Hemmerlein B. Expression of matrix metalloproteinases MMP-2, MMP-9 and their tissue inhibitors TIMP-1, -2 , and -3 in benign and malignant tumours of the salivary gland. Histopathology. 2004;44(3):222-31.

10. Luukkaa H, Klemi P, Hirsimäki P, Vahlberg T, Kivisaari A, Kähäri VM, Grénman R. Matrix metalloproteinase (MMP)-1, -9 and -13 as prognostic factors in salivary gland cancer. Acta Otolaryngol. 2008;128(4):482-90. 